\title{
An ion-based chromogenic method of detecting for inorganic phosphate in serum and milk
}

\author{
Cai-Xia Yin ${ }^{1^{*}}$, Jing Su${ }^{1}$, Fang-Jun Huo ${ }^{2^{*}}$, Pin Yang ${ }^{1}$ \\ ${ }^{1}$ Institute of Molecular Science, Key Laboratory of Chemical Biology and Molecular Engineering of Ministry of Education, Shanxi \\ University, Taiyuan, China; yincx@sxu.edu.cn \\ ${ }^{2}$ Research Institute of Applied Chemistry, Shanxi University, Taiyuan, China; huofj@sxu.edu.cn
}

Received 10 July 2009; revised 21 July 2009; accepted 22 July 2009.

\begin{abstract}
A rapid method for the determination of inorganic phosphate in serum and milk by an ion-based chromogenic is described. Serum samples were detected directly by our system, and milk was also detected after degreased through centrifugation. By this procedure the samples are not diluted. Mean serum inorganic phosphate concentration found in healthy individual is $1.14 \mathrm{mmol} / \mathrm{L}$. Values found in serum is in good agreement with those previously reported. Mean inorganic phosphate concentration from foremilk and commercial milk are $2.5 \mathrm{mmol} / \mathrm{L}$ and $12.5 \mathrm{mmol} / \mathrm{L}$ respectively.
\end{abstract}

Keywords: UV-Vis Spectra; Pyrocatechol Violet; Ytterbium Chloride; Phosphate; Serum; Milk

\section{INTRODUCTION}

Phosphate is involved in important biomineralization processes such as bone formation and also processes that are clearly pathological such as the genesis of renal stones. Consequently, its determination in biological fluids is important [1]. In a clinical setting, inorganic phosphate levels in serum are determined as part of a routine blood analysis. The typical inorganic phosphate concentration in human serum range is $0.81-2.26 \mathrm{mmol} / \mathrm{L}$ [2]. Individuals with abnormally high phosphate levels are diagnosed with hyperphosphatemia, which manifests in acute or chronic renal failure, hypoparathyroidism and excessive Vitamin D intake. And we know that higher serum phosphate levels would be associated with increased mortality risk among people with CKD [3-5]. Those with low inorganic phosphate levels suffer from hypophosphatemia which can be associated with rickets, hyperthyroidism, or Fanoci Syndrome [6-8]. In addition, there is generally a reciprocal relationship between serum calcium and inorganic phosphorus levels. High in- organic phosphorus in serum restrains the intake of calcium.

Regarding the newborn baby, foremilk or milk is the most main headspring they grow on. But exactly this time is the quickest time when young child grows, being in the bone blooming period and the cerebrum and the intelligence still being imperfect stage. So the right amount nutrition could guarantee the normal growth, and prevent malnutrition, rickets, anemia and so on. Especially if absorbing calcium phosphorus imbalance, can cause the low calcium blood sickness, the rickets [9]. Moreover iron in the milk is easy to form insolubly iron compound when affected by high phosphate and calcium, cannot be absorbed by the human body, which may cause the young child to occur lacking the iron anemia. In normal foremilk the calcium phosphorus proportion is 2: 1 , is easy to be absorbed, to prevent and control the rickets. But the milk is $1: 2$, is not easy to be absorbed. Therefore, determination the calcium phosphorus content from foremilk and milk is very important.

Most of the procedure for the colorimetric determination of inorganic phosphate are based on the formation of molybdophosphoric acid with further reduction to heteropolymetric molybdenum blue [10-12] on direct measurements of molybdo- and vanadomolybdophosphoric acid $[13,14]$, or on complex formation between molybdophosphoric acid and basic dyes [15]. These chemical methods have serious shortcomings, however: Molybdate reduction is affected by slight changes in $\mathrm{pH}$, the rate of complex formation is markedly influenced by protein concentration, and the acidity required leads to hydrolysis of organic phosphate, which results in over estimates of $P_{i}$ concentration [16].

In our work, we developed a rapid method for the determination of phosphate in serum and milk by an ion-based chromogenic. Serum samples were detected directly by our system, and milk was also detected after degreased through centrifugation. By this procedure all samples are not diluted. Owing to our system's prominent advantages, it can serve as a hopeful substitute for 
the molybdenum reagent.

\section{MATERIAL AND METHODS}

\subsection{Reagents and Chemicals}

The chemicals used were of analytical-reagent grade. PV (Pyrocatechol violet) was purchased from Shanghai and sodium monhydrogenphosphate was purchased from Beijing. Ytterbium oxide was a product of Rare Earth Graduate School of China. HEPES was purchased from Sigma. All solutions were made up with deionized water. HEPES buffer solutions were obtained by adding $\mathrm{NaOH}$ $0.1 \mathrm{M}$ solution into $10 \mathrm{mM}$ aqueous HEPES using a Beckman $\Phi 50 \mathrm{pH}$ meter. Ytterbium chloride was prepared from ytterbium oxide and 37\% hydrochloric acid. Ytterbium ion solution was prepared by dissolving ytterbium chloride in water. Serum samples were collected from health volunteers and stored at $-17^{\circ} \mathrm{C}$ until analyzed. Cow serum was purchased from commercial pured product. Human milk and commercial milk were degreased through a Centrifugal filter.

\subsection{Instruments and Apparatus}

$\mathrm{pH}$ determinations were performed using a Beckman $\Phi 50 \mathrm{pH}$ meter. UV-v(V)is spectra were recorded on a HP8453 spectrophotometer. PO-120 quartz cuvettes (10mm) were purchased from Shanghai city of China. Finnpipette Digitals were purchased from Shanghai of China. BFX5-320 Low Speed Automatic Balance Centrifuge was purchased from Baiyang Centrifuge factory. Olympus 2700 Complete Automatic Clinical Biochemistry Analysis Apparatus was purchased from Japan.

\subsection{Measurement Procedure}

Using the PV-HEPES-Yb ${ }^{3+}$ ensemble, we detected inorganic phosphorus in serum and milk samples. The procedures were as follows. In 10mM, pH 7.0 HEPES buffer containing $50 \mu \mathrm{M} \mathrm{PV}$ and $100 \mu \mathrm{M} \mathrm{Yb}{ }^{3+}$ (a blue solution), the serum sample from one healthy volunteer was gradually titrated into the solution. At the same time the changes in the absorption peaks of solution in the UV-Vis spectrum were recorded. When no more changes in the absorption peaks of the system took place, titration came to a halt. Then we could calculate the inorganic phosphorus concentration in serum. Likewise, the inorganic phosphorus concentrations of human milk degreased or commercial milk were obtained by above detecting method.

\section{RESULTS AND DISCUSSION}

\subsection{UV-Vis Spectra}

Figure 1a shows the UV-v(V)is spectra obtained when

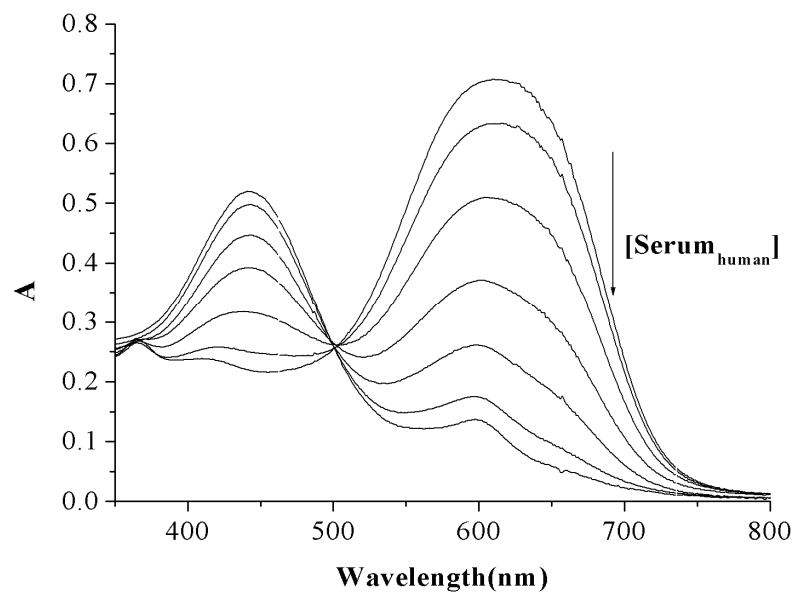

(a)

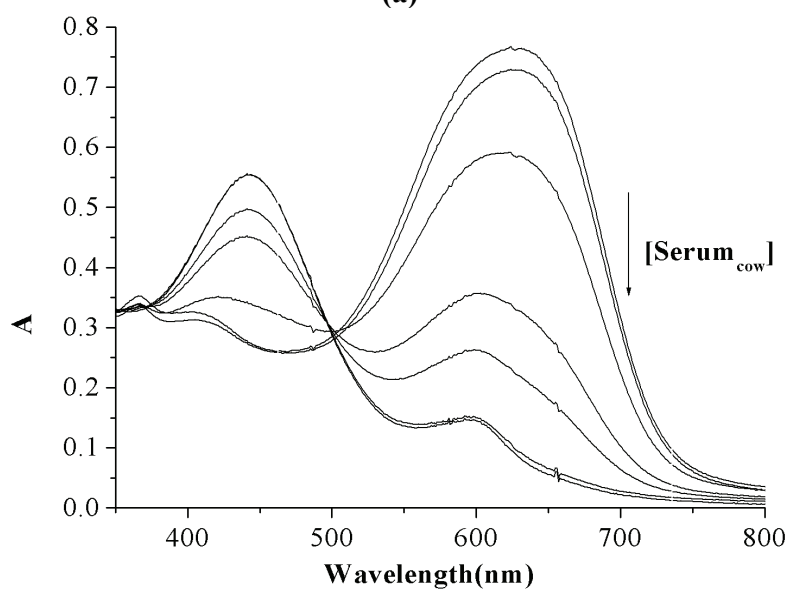

(b)

Figure 1. (a) The serum from human was added into PV-HEPES-Yb ${ }^{3+}$ with Vserum $=0-215 \mu \mathrm{l}$; (b) the serum from cow was added into PV-HEPES-Yb ${ }^{3+}$ with Vserum $=0-90 \mu \mathrm{l}$.

titrating the serum from a health human into the $10 \mathrm{mM}$, pH 7.0 HEPES buffer solution containing $100 \mu \mathrm{M} \mathrm{YbCl}_{3}$ and $50 \mu \mathrm{M}$ PV. With the addition of serum, the absorption peak at $623 \mathrm{~nm}$ decreased, while the peak at $444 \mathrm{~nm}$ increased. When the total volume of added serum reached $210 \mu \mathrm{L}$, titration ended. The concentration of inorganic phosphorus was $0.95 \mathrm{mmol} / \mathrm{L}$. Similarly, Figure 1 b shows $U V-v(V)$ is spectra of serum from cow titrated. The concentration of inorganic phosphorus from cow was $2.20 \mathrm{mmol} / \mathrm{L}$. Figure 2 a shows UV-v(V)is spectra changes when titrating milk from healthy woman into our system. The inorganic phosphorus concentration of milk from lactation mother was $2.31 \mathrm{mmol} / \mathrm{L}$. Figure 2b shows UV-V(V)is spectra changes of milk from commerce process titrated. The inorganic phosphorus concentration of milk from commerce was $11.54 \mathrm{mmol} / \mathrm{L}$.

\subsection{Selectivity over Other Constituents}

In published paper, we addressed the selectivity of the system. We knew that the ensemble exhibited excellent 
selectivity towards phosphate anions over other common anions, including $\mathrm{Cl}^{-}, \mathrm{SO}_{4}{ }^{2-}, \mathrm{CH}_{3} \mathrm{COO}^{-}, \mathrm{HCO}_{3}{ }^{-}$and $\mathrm{ClO}_{4}^{-}$[17]. Serum contains many other organic and inorganic compounds, such as creatinine, bilirubin, sugar, albumen, inorganic salts and transition ion besides the aforementioned ordinary anions. Do these compositions show some responsibility for the changes in the $\mathrm{UV}-\mathrm{v}(\mathrm{V})$ is spectra and color? We took the HEPES buffer as a blank, and then added $200 \mu \mathrm{L}$ serum into it. The result shows that there is no $\mathrm{UV}-\mathrm{v}(\mathrm{V})$ is absorbance in the range of from 350 to $1,000 \mathrm{~nm}$, suggesting that there are no other absorbance peaks coming from other compounds of the serum in the range of detection in the $\mathrm{UV}-\mathrm{v}(\mathrm{V})$ is spectra (Figure 3a). Thus, we may conclude that the changes in the absorbance peak in this range resulted completely from the measurement processes and there was no cumulation or disturbance. To prove that the universal existence of anions in serum incurs no dis-

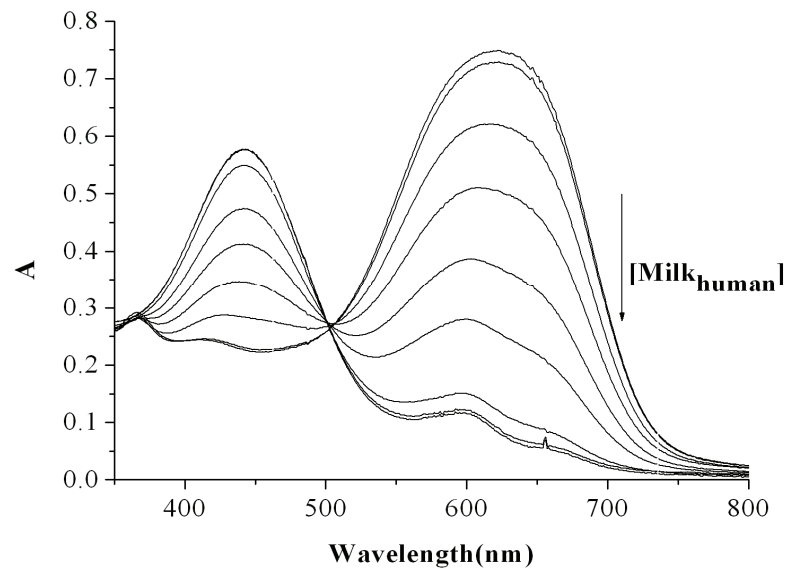

(a) turbance to exclude the possibility of interference from iron or other cations in the measurement, the following experiments were carried out. Firstly, as soon as the excessive $2 \mathrm{mM} \mathrm{YbCl}_{3}$ was added into the $2 \mathrm{mM} \mathrm{HPO}_{4}{ }^{2-}$ solution $\left(\mathrm{V}_{\mathrm{YbCl}} / \mathrm{V}_{\mathrm{HPO} 22}=1.02: 1\right)$, precipitation occurred, a clear solution was gained through centrifugation and decantation processes; the solution (from 0 to $500 \mu \mathrm{L}$ ) was then added into $2 \mathrm{~mL} 10 \mathrm{mM}$ HEPES buffer containing $50 \mu \mathrm{M} \mathrm{PV}$ and $100 \mu \mathrm{M} \mathrm{Yb}^{3+}$, and no changes in absorption peak intensity and color were observed, i.e., no phosphate was detected in the solution, thus suggesting that the $\mathrm{Yb}^{3+}$ could completely remove $\mathrm{HPO}_{4}{ }^{2-}$ from solution by forming sediment. Similarly, we added the excessive $\mathrm{YbCl}_{3}$ into the collected serum samples whose content of $\mathrm{HPO}_{4}^{2-}$ was presumably quantitated with our methods. After the mixture had been treated in accordance with the aforementioned procedures, a great deal of the disposed serum sample $(0-500 \mu \mathrm{L})$ was added into

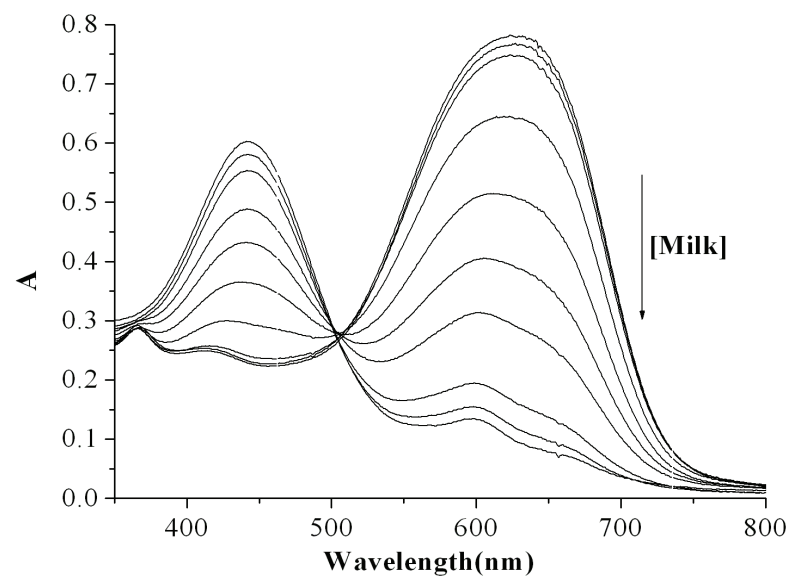

(b)

Figure 2. (a) The milk from woman was added into PV- HEPES-Yb ${ }^{3+}$ with Vmilk=0-65 $\mu$; (b) the serum from cow was added into PV-HEPES-Yb ${ }^{3+}$ with Vmilk $=0-13 \mu$ l.

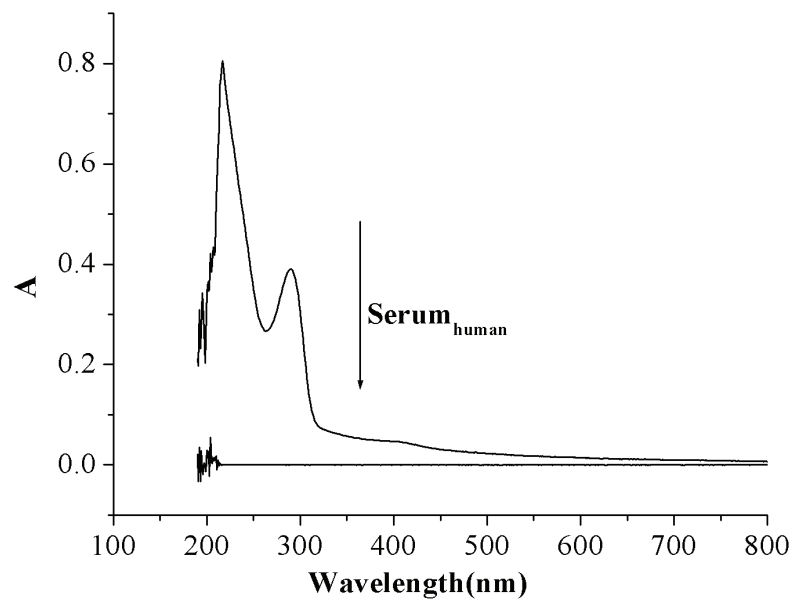

(a)

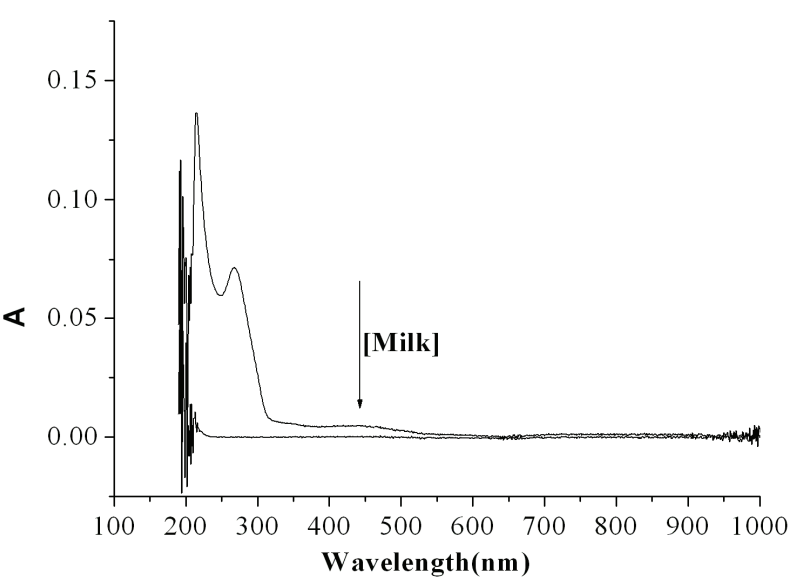

(b)

Figure 3. (a) UV/Vis spectra: Plot of absorbance (at $\lambda=200-1000 \mathrm{~nm}$ ) when adding $20 \mu 1$ urine into HEPES buffer (pH 7.0); (b) when adding $50 \mu \mathrm{l}$ milk into HEPES buffer ( $\mathrm{pH} 7.0)$. 


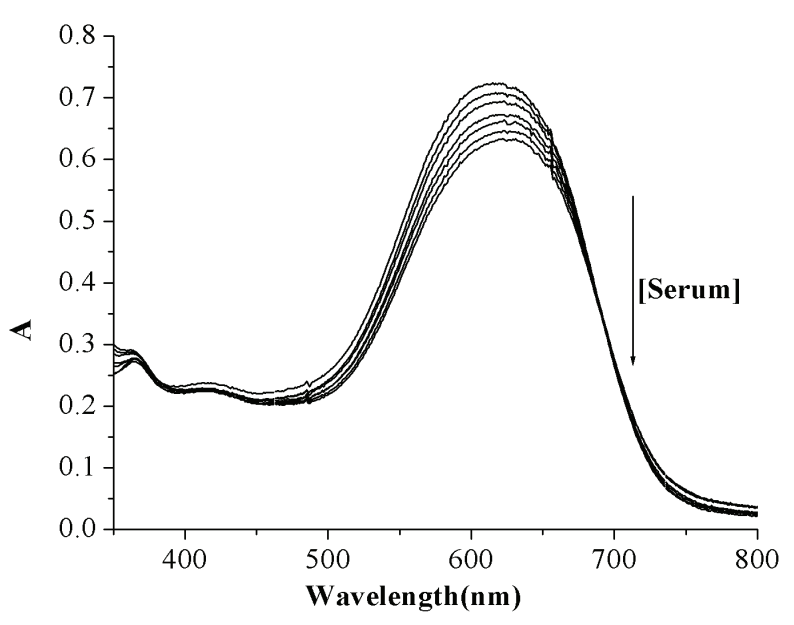

(a)

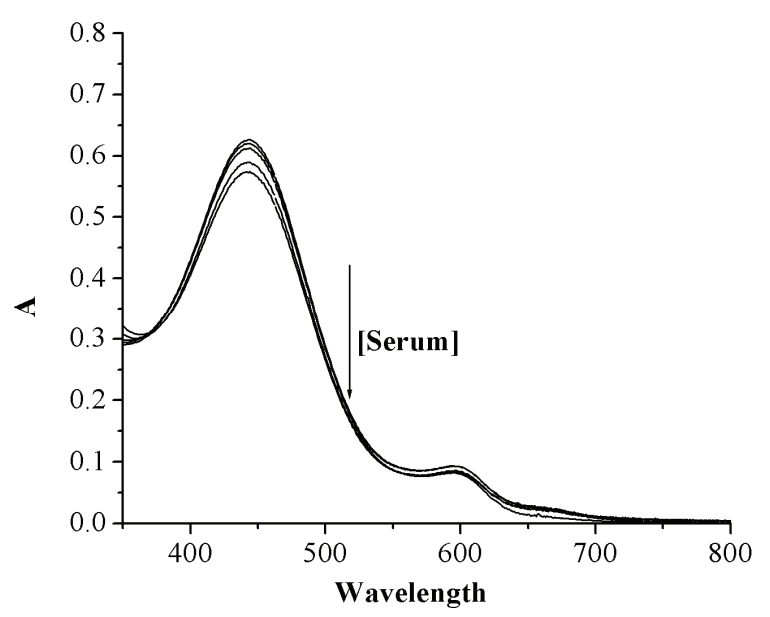

(b)

Figure 4. (a) the disposed serum sample $(0-500 \mu \mathrm{l})$ was added into PV-HEPES-Yb ${ }^{3+}$.(b) UV/Vis spectra $\quad(\lambda=350 \sim 800 \mathrm{~nm}):$ no pretreatment serum sample $(500 \mu \mathrm{l})$ was added into HEPES-PV $(50 \mu \mathrm{M})$.

the $2 \mathrm{~mL} 10 \mathrm{mM}$ HEPES buffer containing $50 \mu \mathrm{M}$ PVand $100 \mu \mathrm{M} \mathrm{Yb}^{3+}$, and no changes were observed in absorption peak intensity and system color(Figure 4a). The experiments excluded the possibility of interference from other anions with the measurement. In addition, we added an adequate amount of unpretreated serum sample into $2 \mathrm{~mL} 10 \mathrm{mM}$ HEPES buffer only containing $50 \mu \mathrm{M}$ $\mathrm{PV}$, and no change in either the $\mathrm{UV}-\mathrm{v}(\mathrm{V})$ is spectra or the system color was observed (Figure 4b). The system was still yellow. The experiments excluded the possibility of interference from iron or other cations with the measurement.

Now, we see about the selectivity of the detection system for milk. We took the HEPES buffer as a blank, and then added $50 \mu \mathrm{L}$ milk into it. The result shows that there is no $\mathrm{UV}-\mathrm{v}(\mathrm{V})$ is absorbance in the range of from 350 to $1,000 \mathrm{~nm}$, suggesting that there are no other absorbance peaks coming from other compounds of the milk in the range of detection in the UV-v(V)is spectra (Figure 3b). Similary process was done for proving no disturbance from other composition of milk. All results ensure that our system is special to phosphate of milk.

\subsection{Linearity and Detection Limits}

Most instrumental methods available for the determination of phosphate in clinical samples have a common drawback; that is, their linear calibration range is too narrow. In our experiment, we plotted the curve with absorbance values at $623 \mathrm{~nm}$ against concentrations $/ 0-2.5 \mathrm{mM} /$ of serum added to the PV-HEPES-Yb ${ }^{3+}$ system. We found our measurement obeyed the BeerLambert absorption law very well within the serum concentration range of $0-2.5 \mathrm{mM}$. Linear regression with least-squares fitting yielded a correlation coefficient of

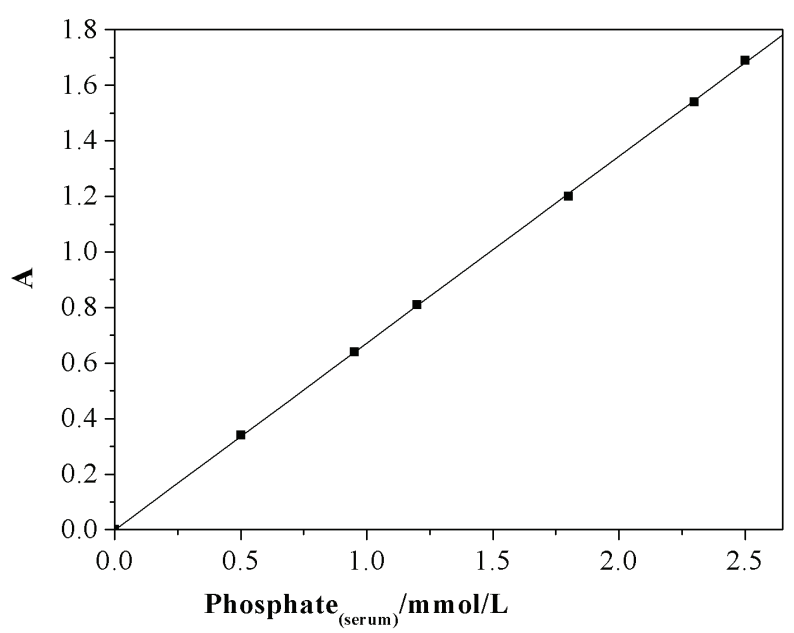

Figure 5. The working curve for serum measurement was plotted with the absorbance value against various concentrations of $\operatorname{serum}(0-2.5 \mathrm{mM})$.

0.99995 (Figure 5). The lower detection limit of our method is around $10^{-4} \mathrm{M}$. And before, we have gotten our measurement obeyed the Beer-Lambert absorption law very well within the urine concentration range of 0-70mM [18]. Phosphorus concentrations of milk from woman or commerce are not higher than $70 \mathrm{mM}$, so this linear calibration range is enough for milk.

\subsection{Validation}

In order to validate the accuracy of the method, we detected serum samples by the standard procedure (molybdenum blue assay for phosphate) and obtained equivalent results with our measurement. Figure 6 and Table 1 give the results (spectra) for serum obtained with the two kinds of detection methods. Finally, the recovery experiments were performed: The results are 


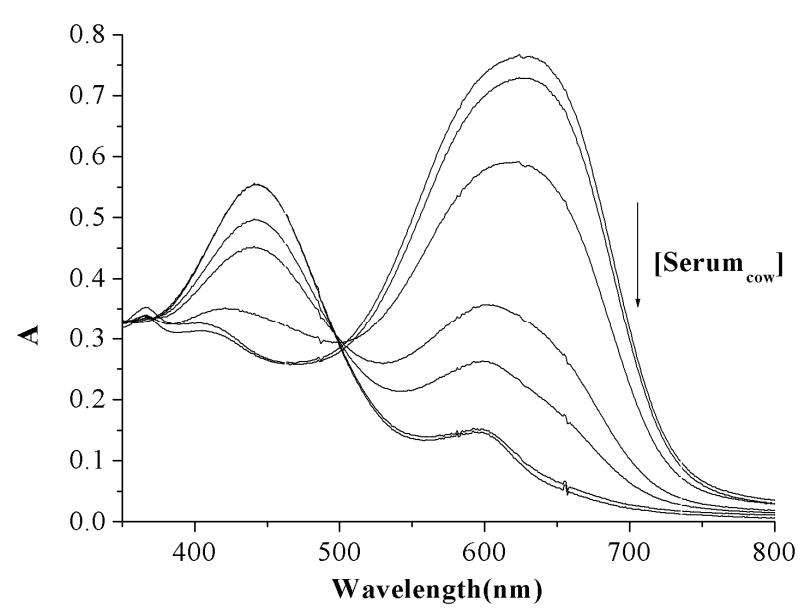

(a-1)

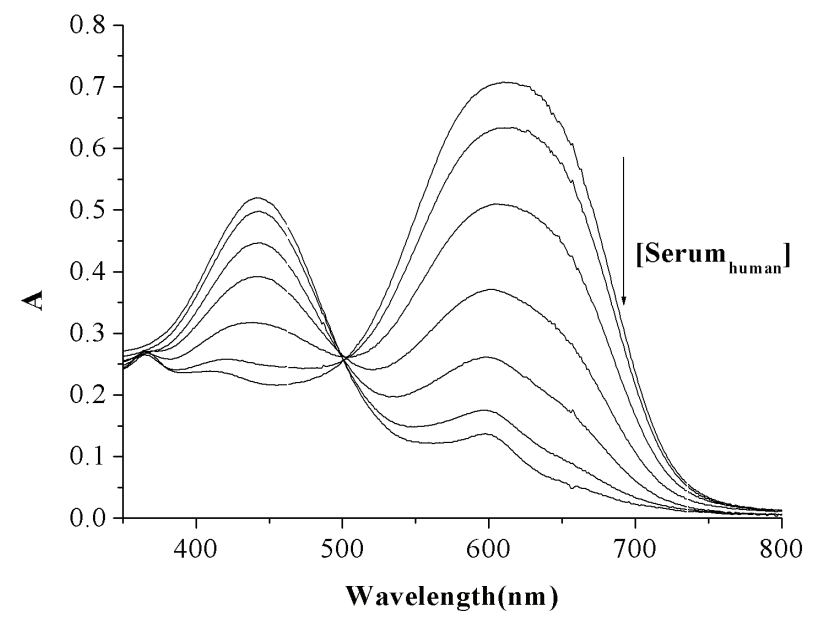

(b-1)

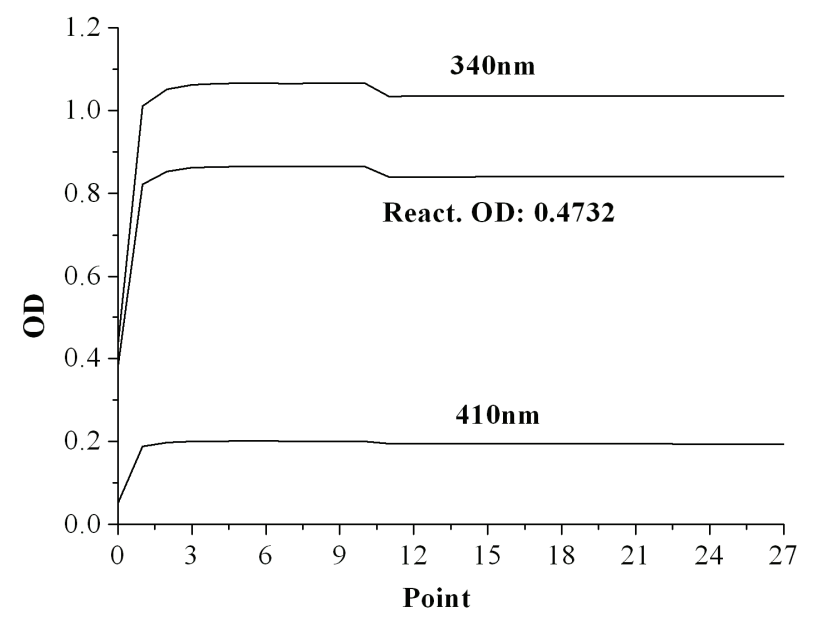

(a-2)

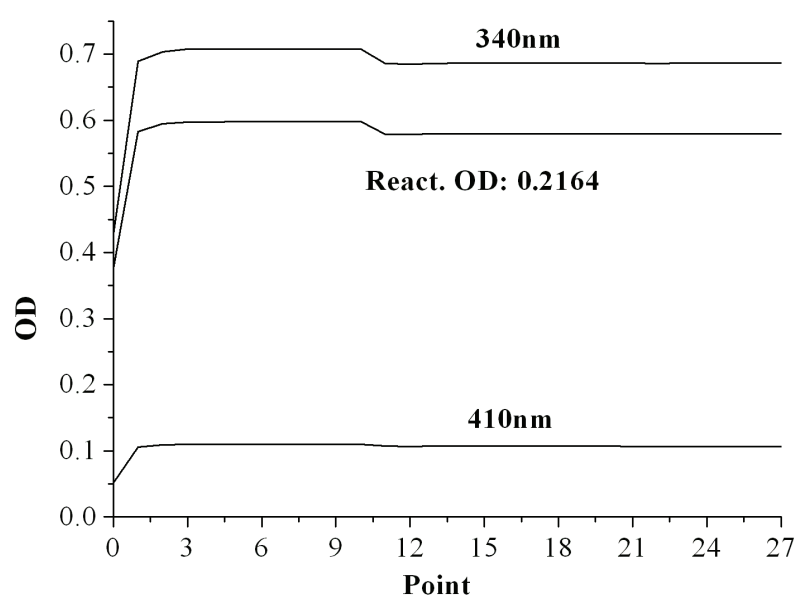

(b-2)

Figure 6. (a)Left: Uv-Vis spectra of cow serum sample Inorganic Phosphorus concentration from our method(2.20 mmol/L); Right: the results from Molybdenum blue assay for phosphate respectively $(2.22 \mathrm{mmol} / \mathrm{L}$; (b) Left: Uv-Vis spectra of serum sample Inorganic Phosphorus concentration from our method $(0.95 \mathrm{mmol} / \mathrm{L})$; Right: the results from Molybdenum blue assay for phosphate $(0.93$ $\mathrm{mmol} / \mathrm{L})$.

compiled in Table 2. The results indicated the accuracy of the method, as expressed by the calculated recovery values, was satisfactory.

\subsection{Analysis of Results}

From our data, we can see inorganic phosphorus content of milk is higher than foremilk about five times. This indicates the excessive inorganic phosphorus is disadvantageous to young child's growth. And with the people level of living enhancement, the commercial milk becomes the people basic nutriment. But in the processing commercial milk many important ingredients content are insufficient, for instance, the calcium, phosphorus ratio of is 2: 1 in milk containing the few calcium, many phosphorus, is easy to form the insoluble calcium phosphate, affects the intestinaltract absorbing calcium and phosphorus. If provide turnips containing many calcium, few phosphorus for the child who eats the milk, can correct calcium and phosphorus proportion, namely can enhance the calcium absorbing capacity. Therefore, the reasonable increase and the adjustment can only prevent to be out of nutrition balance for one people drink milk.

\subsection{Assay Advantage}

Ion-based chromogenic method has proved to be a useful tool for clinical analysis because of its simplicity, repeatability, low reagent consumption and so on. We know that ion chromatography, the use of deproteinizing agents presents several disadvantages: perchloric acid and trichloroacetic acid need to be removed from the sample by time-consuming procedures otherwise they 
Table 1. Results of our method against the method (molybdenum blue assay for phosphate).

\begin{tabular}{|c|c|c|}
\hline $\begin{array}{r}\text { Numbers of } \\
\text { serum sample }\end{array}$ & $\begin{array}{c}\text { Phosphate } \\
\left(\mathrm{mmolL}^{-1}\right) \text { from } \\
\text { Molybdenum blue } \\
\text { assay }\end{array}$ & $\begin{array}{c}\text { Phosphate } \\
\left(\mathrm{mmolL}^{-1}\right) \text { from } \\
\text { our method }\end{array}$ \\
\hline $1\left(\right.$ Serum $\left._{\text {human }}\right)$ & 0.96 & 0.97 \\
\hline $2\left(\right.$ Serum $\left._{\text {human }}\right)$ & 0.93 & 0.95 \\
\hline $2\left(\right.$ Serum $\left._{\text {cow }}\right)$ & 2.20 & 2.22 \\
\hline
\end{tabular}

Table 2. Recovery of phosphate in serum and milk.

\begin{tabular}{cccc}
\hline Sample & $\begin{array}{c}\text { Added } \\
\text { (phosphat) } \\
\text { mmolL }^{-1}\end{array}$ & $\begin{array}{c}\text { Found } \\
\text { (phosphate) }_{\text {mmolL }^{-1}}\end{array}$ & $\begin{array}{c}\text { Recovery } \\
\text { (\%) }\end{array}$ \\
\hline 1(Serum) & - & 1.48 & \\
& 0.6 & 2.02 & 95.9 \\
2(Serum) & - & 1.11 & \\
& 0.6 & 1.73 & 102 \\
3(Serum) & - & 0.95 & \\
& 0.6 & 1.53 & 97.3 \\
4(Milk & - & 2.34 & \\
& 1.0 & 3.42 & 104 \\
5(Milk & & 12.5 & \\
& - & 17.3 & 98.4 \\
\hline
\end{tabular}

interfere with the elution profile; organic solvents such as acetonitrile lead to damage to the column and sulphosalicylic acid is often contaminated with sulphate, lead to sample dilution. And our method decreases the cost of analyses with respect to batch methods involving enzymes in solution. All these advantages make the method reported here be a valid alternative for the determination of phosphate in serum.

\section{CONCLUSIONS}

To sum up, we developed a sensitive, rapid and direct method for detecting serum and milk phosphate spectrophotometrically. Our method is suitable for performing direct determinations of phosphate in serum without any pretreatment and any interference. Now more and more people are suffering from lithiasis as a result of better living standards. Timely inspection of serum phosphate is one of the clinical means of diagnosis. Since long-time, people only pay attention to the inorganic phosphorus determination in the urine and the blood serum, to determine the inorganic phosphorus in the foremilk mother's milk and milk method very little was mentioned. In this paper, we use our invention system to quantificationally determine inorganic phosphorus concentration from milk degreased through centrifugation, the results are accurate, suit to clinical and the commerce use.

\section{ACKNOWLEDGEMENTS}

We acknowledge to the financial support of this work by the National Natural Science Foundation of China (No. 20801032), Shanxi Provincial Natural Science Foundation (No. 2009021006-2) and the Shanxi Province Foundation for Returness (2008).

\section{REFERENCES}

[1] Grases, F. and March, J. G. (1990) Determination of phosphate based on inhibition of crystalline growth of calcite. Analytica Chimica Acta., 229, 249-254.

[2] Ender, D. B. and Rude, R. K., (1999) Mineral and bone metabolism, In Tietz Textbook of Clinical Chemistry (C. A. Burtis, E. R. Ashwood, Eds.), W. B. Saunders, company: P. A. Philadelphia, 1406-1408,1439-1440.

[3] Kestenbaum, B., Sampson, J. N., Rudser, K. D., et al. (2005) Characterization of phosphate transport in rat vascular smooth muscle cells. J Am Soc Nephrol., 16, 520-528.

[4] Levi, M. and Knochel, J. P. (1990) The management of disorders of phosphate metabolism. In Therapy of Renal Diseases and Related Disorders (S. G. Massry, W. N. Suki,), Boston, Martinus Nijhoff.

[5] Levi, M., Cronin, R. E., and Knochel, J. P. (1992) Disorders of phosphate and magnesium metabolism. In Disorders of Bone and Mineral Metabolism (F. L. Coe, M. J Favus,), New York: Raven Press.

[6] Biochrom Ltd Certificate No: 890333 Determination of phosphate in clinical samples.

[7] Popovtzer, M., Knochel, J. P., and Kumar, R. (1997) Disorders of calcium, phosphorus,vitamin D, and parathyroid hormone activity. In Renal Electrolyte Disorders, edn 5 (R. W. Schrier,) Philadelphia: Lippincott-Raven.

[8] Hruska, K. and Gupta, A. (1998) Disorders of phosphate homeostasis. In Metabolic Bone Disease, edn 3 (L. V. Avioli, S. M. Krane,) New York: Academic Press.

[9] Greer, F. R., Steichen, J. J., and Tsang, R. C., (1982) Calcium and. phosphate supplements in breast milk- related. Rickets. Am J Dis Child., 136, 581-583.

[10] Fiske, C. H. and Subbarow, Y. J. (1925) The colorimetric determination of phosphorus. Biol. Chem., 66, 375-400.

[11] Lowry, O. H. and Lopez, J. A. (1946) The determination of inorganic phosphate in the presence of labile phosphate ester. J. Biol. Chem., 182, 421.

[12] Bartles, P. C. and Roijers, A. F. M. (1975) A kinetic study on the influence ofparameters in the determination of inorganic phosphate by the molybdenum blue reaction. Clin. Chim. Acta., 61, 153-4.

[13] Daly, J. A. and Ertingshausen, G. (1972) Direct method for determining inorganic phosphorus in serum. with the Centrifichem. Clin. Chem., 18, 263-265.

[14] Urban, A. E. (1972) Simplified. serum phosphorus. analyses. by continuous-flow. ultraviolet. Spectrophotometry. J. Clin. Chem., 18, 601-4.

[15] Fogg, A. G., Soleymanloo, S., and Burns, D. T. (1977) The spectrophotometric determination of inorganic phosphate in biological system with crystal violet. Anal. Chim. Acta., 88, 197-200. 
[16] Endres, B. D. and Rude, R. K. (1994) Mineral and bone metabolism. Tietz textbook of clinical chemistry (C. A. Burtis, E. R. Ashwood, eds.), Philadelphia: W. B. Saunders, Co., 1887-973.

[17] Yin, C. X., Huo F. J., and Yang, P. (2005) An ion-based chromogenic detecting method for phosphate-containing derivatives in physiological condition. Sensors and Actuators B Chemical., 109, 291-299.

[18] Yin, C. X., Huo, F. J., Yang, P. (2006) UV-Vis spectroscopic study directly detecting inorganic phosphorus in urine and our reagent kit. Anal Bioanal Chem., 384, 774-779. 